\title{
Florida Crop/Pest Management Profile: Mango ${ }^{1}$
}

\author{
Mark A. Mossler and Jonathan Crane ${ }^{2}$
}

\section{Production Facts}

- The mango acreage in Florida is approximately 2,000 acres, which represents approximately 200,000 trees (1).

- Production in Florida is estimated to be 100,000 bushels (5.5 million pounds) annually, although yearly production can vary greatly. At a price of $\$ 21$ per bushel, this crop is worth $\$ 2.1$ million $(1,2)$.

\section{Production Regions}

Mango (Mangifera indica) is grown primarily in south Florida. In 2000, 83 percent of Florida's mango acreage was located in Miami-Dade County. The remainder of mango acreage is located in Lee, Palm Beach, and other counties with the appropriate climate $(1,3)$.

\section{Production Practices}

The mango tree is classified as an evergreen and is in the Anacardiaceae family. It is indigenous to India and Southeast Asia and was first introduced into Florida in 1833. The tree can grow to a height of 100 feet, but it is generally maintained at a height of 20 feet for ease of harvest and maintenance. Leaves are alternate, lanceolate shaped, and six to 16 inches in length. The fruit vary in shape (kidney, round, oblong, oval), and weight ranges from a few ounces to five pounds. Although the fruit will ripen on the tree, it is usually picked green for shipment. The crop is considered mature when the shoulder of the fruit broadens (fills out) and some fruits on the tree have begun to change color from green to yellow. Prior to this color change, the fruit is considered mature when the flesh near the seed changes color from white to yellow (3).

Mango should be planted in soil with adequate drainage, although some varieties withstand flooding for brief periods. Prolonged flooding leads to leaf wilt/desiccation, stem dieback, reduced growth, and tree death. Since mango is adapted to lowland subtropical and tropical climates, it does have a high water requirement. During seedling establishment and dry periods, irrigation systems should be able to provide supplemental irrigation (3).

Cultivars commonly used in Florida mango production are 'Tommy Atkins' and 'Keitt' as well as 'Palmer', 'Van Dyke', and 'Kent'. Rootstocks used include 'Turpentine' and 'Number 11'. These rootstocks are tolerant of high $\mathrm{pH}$, and seedlings are vigorous and relatively uniform. Mango cultivars are classified as monoembryonic (Indian type) and polyembryonic (Indochinese type). The former are those cultivated in Florida while the latter serve as rootstock. Consequently, most commercial mango is propagated vegetatively. Veneer-grafting and chip-budding techniques are most often used with greatest success in warm months. Grafted trees produce marketable fruit within three to five years $(3,4)$

1. This document is CIR 1401, one of a series of the Horticultural Sciences Department, Florida Cooperative Extension Service, Institute of Food and Agricultural Sciences, University of Florida. Original publication date March 2002. Original authors included O. Norman Nesheim, professor, Food Science and Human Nutrition Department. This publication was revised November 2009. Reviewed July 2013. For additional Information, contact the Pesticide Information Office, University of Florida, P. O. Box 110710, Gainesville, Fl 32611-0710, (352) 392-4721. Please visit the EDIS Website at http:// edis.ifas.ufl.edu.

2. Mark A. Mossler, pest management information specialist, Department of Agronomy, Pesticide Information Office; and Jonathan Crane, professor, Horticultural Sciences Department, Tropical Research and Education Center, Homestead, Florida; Cooperative Extension Service, Institute of Food and Agricultural Sciences, University of Florida, Gainesville, FL 32611-0710. 
Mango trees are planted from 10 to 30 feet apart within rows and from 20 to 30 feet between rows. Consequently, a mature stand would have about 100 trees per acre. Formative pruning of young trees is not necessary. Commercial producers periodically cut back growth to allow better penetration of sprays and ease of picking. Pruning is performed mechanically after fruit harvest, which is generally done two to four times per season (3).

The mango inflorescence may possess 1,000 to 4,000 flowers, but less than one fruit per panicle is set by most commercial mango varieties. Despite this, yields of 165 to 440 pounds of fruit per tree may be produced. Mango blooms from December to April, depending on variety, and the fruit takes 100 to 150 days to mature. Consequently, the greatest production in Florida is from May through September. Pollination is by insects such as thrips, flies, and bees. A dry season prior to and during the blooming period is considered optimal for good fruit production (3).

The best temperatures for ripening mangos are $70-75^{\circ} \mathrm{F}$ $\left(21-24^{\circ} \mathrm{C}\right)$. Fruit ripened at higher temperatures often shrivels and develops off-flavors. Fruit can be held at temperatures no colder than $55^{\circ} \mathrm{F}\left(13^{\circ} \mathrm{C}\right)$ to delay ripening (3).

Computer-aided pest management of tropical fruit has been implemented by the University of Florida, Institute of Food and Agricultural Sciences. The TFRUIT•Xpert diagnostic program has been developed to assist growers and others in determining diseases, insect pest problems and physiological disorders (http://it.ifas.ufl.edu/software/ tropicalfruits cd.html).

Worker Activities Mango trees are picked by hand or by using a long picking pole which has at its distal end a canvas or nylon bag attached to a metal ring with a cutting blade. Ladders and hydraulic lifts are also used to enable pickers to reach fruit high in the tree canopy. A worker can generally pick up to three acres daily. Workers may also spend several weeks a year pruning mango tree limbs (1).

\section{Insect/Mite Management}

\section{Insect/Mite Pests}

The principal pests on mango in Florida are mites (avocado red mite, mango spider mite, mango bud mite), scales (dictyospermum scale, Florida red scale, Florida wax scale, pyriform scale, oleander scale, mango scale, plumose scale), thrips (redbanded, flower), and ambrosia beetles. Minor and occasional pests include aphids, mealybugs, and whiteflies/blackflies $(1,3)$.
Mites (Oligonychus yothersi, Oligonychus mangiferus, Aceria mangiferae) Spider mites of the genus Oligonychus commonly infest mangos in Florida. Feeding is first confined to the upper leaf surface, along the midrib, and then along secondary veins. The areas along the veins become reddishbrown. Damage by the spider mites is regularly observed from October through February, causing a reduction in photosynthesis of up to 30 percent. Infested leaves often abscise prematurely. Control measures are often started when mite pressures reach six or more mites per leaf. For spider mites in general, life cycles may last several weeks. The female lays 40 to 50 eggs over a lifetime, and they are capable of overwintering within the grove $(1,3)$.

Mango bud mite (A. mangiferae) is found on buds and is associated with two diseases depending on the presence of Fusarium sp. fungi. When the fungus is absent and the buds are attacked, a witch's broom develops at the terminal branch. When the fungus is present, galls form on flowers and foliage $(1,3)$.

Scale (Chrysomphalus dictyospermi, Chrysomphalus aonidum, Ceroplastes floridensis, Protopulvinaria pyriformis, Aspidiotus nerii, Radionaspis indica, Morganella longispina) Soft and armored scales are plant-feeding insects which are often controlled by natural and released parasites, predators, and pathogens. In cases when the natural balance of predation has been disrupted, scale populations may increase to levels requiring treatment. Since scale insects are relatively immobile and at least one month is required for the egg to reach the adult stage, an infestation builds up slowly (in comparison to mites or aphids) and may be hard to spot. It is also important to verify that the scale insects attached to the plant are alive, as mummies accumulate on the plant over time. Economic thresholds for scale have not been determined. Most effective control is obtained when the scales are in nymphal stages because egg and adult stages are recalcitrant to insecticide applications (5).

Thrips (Selenothrips rubrocinctus, Frankliniella bispinosa, Frankliniella kelliae) The redbanded thrips is ubiquitous in its distribution throughout Florida, but it is generally found in damaging numbers from Orlando to Key West. Female redbanded thrips are slightly greater than $1 \mathrm{~mm}$ in length and have a dark brown to black body. The black color is underlain by red pigment, chiefly in the first three abdominal segments. The larvae are light yellow to orange, with the first three and last segments of the abdomen bright red. The life cycle of this thrips is about three weeks in Florida, and several generations are possible each year. In addition to attacking avocado and mango, this thrips also attacks sweetgum trees. Redbanded thrips prefer young foliage, 
which may lead to leaf drop, at times totally denuding trees. The frass and associated sooty mold from thrips feeding gives rise to fruit which is out-of-grade (6).

In Florida, the thrips complex consisting of the two Frankliniella species is the most frequently observed blossom pest. It causes damage by ovipositing in the panicle and feeding on the floral nectaries and anthers, which may result in premature loss of pollen. These thrips are light-yellow and appear commonly during the dry season from January to April (3).

Ambrosia Beetles (Xylosandrus spp.) The scolytid beetles of this genus attack the main stems and branches of mango trees. Secondary fungal infections extend terminally and basally from the beetle gallery in the tree and can kill the affected branches. The insect prefers trees that have been weakened by stress (wind, drought, etc). However, once a population has been established in a planting, the infestation spreads to healthy trees (3).

\section{Chemical Control}

Sixty-four percent of responding mango growers surveyed reported insecticide use. Those survey respondents that provided insect damage estimates indicated that from 10 to 100 percent of the mango crop would be lost to insect damage ( $n=7$, mean of 45 percent) (7). Insecticides and miticides registered for use on Florida mango in 2008 include azadirachtin, Bacillus thuringiensis, Beauveria bassiana, buprofezin, imidacloprid, insecticidal oil, insecticidal soap, malathion, methidathion, methoxyfenozide, pyrethrin $+/$ - rotenone, pyriproxyfen, spinetoram, spinosad, and sulfur. Pyriproxyfen and methoprene are available for fire ant control (8).

In non-bearing mango, bifenazate and bifenthrin are registered, and pymetrozine, fenpropathrin, and hexythiazox are labeled for non-bearing nursery mango. Hydramethylnon and fenoxycarb are available for fire ant control in nonbearing mango.

\section{Crop Oils}

Crop oils work by smothering immobile insects such as scales, aphids, and mites. The oils are usually made up as 1.5 to 3 percent solutions which are applied thoroughly to each tree. Price varies based on amount and formulation used, but an average application cost is $\$ 6 /$ acre (9). The restricted entry interval (REI) for crop oils is 4 hours, and there is no pre-harvest interval (10). Fifty percent of surveyed mango growers in Florida applied oil to their acreage once ( 43 percent), twice ( 43 percent), or four times
(14 percent) per season for an average use of 1.9 times per season (7).

\section{Malathion}

Malathion is an organophosphorous compound which causes death by interfering with proper nerve transmission. Malathion is used to control a variety of insect pests. The median price of malathion is $\$ 6$ per pound of active ingredient and the approximate cost per application is $\$ 5$ per acre $(9,11)$. The pre-harvest interval (PHI) is 2 days, and the REI is 12 hours (11). Twenty-one percent of surveyed mango growers in Florida applied malathion to their acreage three times (66 percent) or five times (33 percent) for an average use of 3.6 times per season (7).

\section{Methidathion}

Methidathion is an organophosphate insecticide used to manage sucking insects such as scale and mealybug (1). The price of methidathion is $\$ 29$ per pound of active ingredient, and the approximate cost per application is $\$ 7$ per acre $(9,12)$. There is a maximum of five applications per year, and all applications must be made after harvest and before bloom. The REI is 48 hours (12). Thirty-six percent of surveyed mango growers applied methidathion to their acreage once ( 60 percent), twice ( 20 percent), or three times (20 percent) for an average use of 1.6 times per season (7).

\section{Pyrethrin + Rotenone}

These two natural compounds both have contact and stomach activity (13). The mixture is used to manage sucking and chewing insects. The median price of the mixture is $\$ 900$ per pound of active ingredient and the approximate cost per application is $\$ 25$ per acre $(9,13)$. The PHI and REI are both 12 hours (13). Seven percent of mango growers reported the use of Pyrellin ${ }^{\circledR}$ twice a year (7).

\section{Bacillus Thuringiensis}

The biopesticide Bacillus thuringiensis (B.t.) is used to manage lepidopteran larvae. The median price of B.t. is $\$ 140$ per pound of active ingredient and the approximate cost per application is $\$ 13$ per acre $(9,14)$. B.t. may be applied up to the day of harvest $(\mathrm{PHI}=0$ day), and the REI is 4 hours (14). Seven percent of surveyed mango growers in Florida applied B.t. to their acreage twice per season (7). 


\section{Imidacloprid}

Imidacloprid is a neonicotinoid insecticide which induces anti-feeding behavior, particularly in sucking insects. The compound is used to manage thrips and whiteflies. The price of imidacloprid is $\$ 250$ per pound of active ingredient and the approximate cost per application is $\$ 20$ per acre $(9,15)$. The PHI for imidacloprid is 30 days and the REI is 12 hours (15). No more than 0.083 pounds of active ingredient per acre may be applied per application and the seasonal maximum is 0.5 pounds of active ingredient. There must be seven days at a minimum between applications. The material is not to be applied during bloom or when bees are present (15). Seven percent of mango growers in Florida applied imidacloprid to their acreage once per season (7).

\section{Cultural Control}

Based on survey results of all tropical-fruit-growing respondents, 44 percent reported keeping records of pest problems, 50 percent adjusted applications (timing or rate) to protect beneficial insects and mites, and 52 percent alternated pesticides to reduce resistance. Sixty-two percent reported selecting the pesticide that is least toxic to beneficial insects and mites and 63 percent spot sprayed only infested plants or areas. Seventy percent reported selecting pesticides that are least toxic to the environment to make this the dominant form of cultural pest control (7).

\section{Biological Control}

Seven percent of the responding tropical fruit growers reported release of predatory wasps for control of lepidopteran pests. Additionally, 30 percent reported the use of biological-derived pesticides like B.t (7).

\section{Weed Management}

\section{Weed Pests}

Weeds can reduce mango yields by competing primarily for water and nutrients. Although individual weed species may vary regionally, predominant weed species in groves are grasses, sedges, and pigweeds (16).

\section{Chemical Control}

There are few herbicides labeled for use on bearing mango (glyphosate, carfentrazone, and pelargonic acid). Fluazifop and diquat can be used on non-bearing mango trees (8). All of these herbicides are used to control weeds between trees. Eighty-six percent of mango growers surveyed reported herbicide use (7).

\section{Glyphosate}

Glyphosate is a phosphorylated amino acid herbicide used for total vegetation control. Glyphosate is applied as a directed spray so that mango foliage is not injured. The median price of glyphosate is $\$ 10$ per pound of active ingredient and the approximate cost per application is $\$ 20$ per acre for annual weeds and $\$ 50$ per acre for perennial weeds $(9,17)$. The REI for glyphosate is 4 hours and the PHI is 14 days (17). Eighty-six percent of surveyed mango growers in Florida applied glyphosate either one (8 percent), two (18 percent), three ( 8 percent), four (50 percent), five ( 8 percent), or six (8 percent) times for an average seasonal use of 3.6 times (7).

\section{Disease Management Disease Pathogens}

Fungi and algae are responsible for the principal diseases affecting mango production in Florida. The most recurrent and problematic diseases include anthracnose (Colletotrichum gloeosporioides), powdery mildew (Oidium spp.), scab (Elsinoe mangiferae), spot (Pestalotiopsis mangiferae, Phyllosticta anacardeacearum), and wilt (Verticillium alboatrum). Algal spot (Cephaleuros virescens) may become prevalent in late summer through late winter. Other diseases that intermittently affect mango production are dieback (Botryodiplodia theobromae, Botrysphaeria ribis), stem-end rot (Diplodia spp., Phomopsis spp.) and witch's broom (Fusarium subglutinans) $(1,17)$.

\section{Anthracnose (caused by Colletotrichum gloeosporioides)}

Anthracnose can occur on all parts of the mango tree. Leaf infection starts as small, dark, angular to irregular spots. These often coalesce to form large necrotic areas, which may crack. Infections on the flower panicle appear as small brown or black spots which enlarge and often coalesce to cause the death of flowers. Small fruit are rapidly invaded by the fungus once they become infected. On nearly mature or ripe fruit, black spots coalesce to cover large areas, which may be sunken. Surface "tear staining," a phenomenon caused by spores falling from an inoculum source above the fruit, may be apparent (17).

\section{Powdery Mildew (caused by Oidium spp.)}

In severe attacks, the entire blossom panicle may be involved and fruit fail to set. Infected flowers, flower stalks, and young fruit become coated with the whitish powdery growth of the pathogen and the flowers and young infected fruits are similarly coated with the white fungal growth. 
Younger leaves may become distorted. On older leaves and fruit, infected tissue has a purplish-brown cast, as the white growth weathers away. The infection on fruit may also appear as an irregular blotch. Affected fruit may turn brown and fall off the tree. The disease is a particular problem in cool dry years (17).

\section{Scab (caused by Elsinoe mangiferae)}

Scab is a pathogen of young leaves and colonization is favored in cool, wet conditions. Signs of scab on leaves are small spots on the underside of leaves, which turn from dark-brown to gray. Leaves may become distorted and twisted if the infestation is heavy. Gray lesions on twigs may also be apparent. Fruit develops irregular, gray lesions which enlarge as it matures. The lesion centers become corky and cracked, and often exhibit the velvety growth of the fungus in moist weather (1).

Leaf Spot (caused by Pestalotiopsis mangiferae and Phyllosticta anacardeacearum)

Both of these fungi cause leaf spot in mango, but with slightly different appearances. P. mangiferae spots are gray and irregularly shaped. They may range from a few millimeters to several centimeters in diameter. P. anacardeacearum leaf spots are bleached to white in color and can be numerous on leaves. Both fungi form black dot-like reproductive structures in the lesion centers (1).

\section{Algal Spot (caused by Cephaleuros virescens)}

This alga commences colonization late in the summer and progresses through the winter months. Initially hard to visualize, green, yellow-green, or rust colored leaf spots up to $5 \mathrm{~mm}$ in size become raised and roughly circular. Stems may develop cankers where infestation is high. The alga eventually produces rust-colored "spores." - These will give rise to more algae if not controlled with copper sprays (17).

\section{Verticillium Wilt (caused by Verticillium albo-atrum)}

This soil-borne fungus is more prevalent in trees planted in historic areas of solanaceous crop production. The fungus invades water-conducting structures in the roots, causing a persistent wilt, which is often one-sided on the tree. Brown or gray streaks may be observed in the vascular tissue once the bark is peeled away. Leaves may die for lack of water but remain attached for some time. Trees also may flush out with new shoots several months after collapse, apparently recovered from the infection (17).

\section{Chemical Control}

Ninety-three percent of mango growers surveyed reported fungicide use (7). Those survey respondents that provided damage estimates indicated that from 5 to 100 percent of the mango crop would be lost to disease ( $n=13$, mean of 73 percent) (7). Fungicides registered for use on mango include azoxystrobin, chlorothalonil, mefenoxam, myclobutanil, hydrogen dioxide, copper, sulfur, carbonic acid, phosphite, and ferbam. Bacillus subtilis and B. pumilus are both labeled for mango as well. Thiabendazole is labeled for post-harvest treatment of mango (8).

\section{Copper}

Copper has long been used as a fungicide and can be applied in multiple forms (copper hydroxide, copper sulfate, etc.). Copper is used to manage anthracnose, scab, and algal spot (19). The median price of copper hydroxide is $\$ 2$ per pound of active ingredient and the approximate cost per application is $\$ 13$ per acre $(9,19)$. The PHI and REI for copper hydroxide are 0 day and 24 hours, respectively (19). Based on survey results, 79 percent of mango growers in Florida applied copper either twice ( 9 percent), four times (9 percent), five times (18 percent), six times (37 percent), eight times (9 percent) or ten times (18 percent) per season for an average seasonal use of 6.2 times (7).

\section{Sulfur}

As with copper, sulfur has long been used as a fungicide and can be applied in the form of copper sulfate or elemental sulfur. Sulfur is used to manage powdery mildew and anthracnose (as well as mites occasionally). The median price of sulfur is $\$ 1$ per pound of active ingredient, and the approximate cost per application is $\$ 21$ per acre $(8,20)$. The PHI and REI for sulfur are 0 day and 24 hours, respectively (20). Based on survey results, 50 percent of mango growers in Florida applied sulfur either twice (44 percent), four times (14 percent), six times (14 percent), eight times (14 percent), or ten times (14 percent) per season for an average use of 4.8 times (7).

\section{Ferbam}

Ferbam is an iron-containing dithiocarbamate fungicide that is used to manage anthracnose in mango under a special local needs registration. The median price of ferbam is $\$ 4$ per pound of active ingredient and the approximate cost per application is $\$ 17$ per acre (21). The PHI and REI for ferbam are 0 days and 24 hours, respectively. No more than 60.8 pounds of active ingredient may be applied per season (21). Based on survey results, 43 percent of mango growers 
in Florida applied ferbam once (17 percent), twice (32 percent), ten times (17 percent), twelve times (17 percent), or sixteen times (17 percent) per season for an average use of 7.3 times (7).

\section{Post-harvest Control}

Careful handling during and after harvest, removal of infected mangos during grading, and adequate temperature maintenance can all aid in minimizing losses from post-harvest decays. In addition to the causative agent of anthracnose (Colletotrichum gloeosporioides), post-harvest disease organisms that can cause rotting include Diplodia spp. and Phomopsis spp. (1).

\section{Nematode Management}

\section{Nematode Pests}

Plant-parasitic nematodes are microscopic roundworms, found in soils, which primarily attack plant roots. General signs of nematode damage include stunting, premature wilting, leaf yellowing, root malformation, and related symptoms characteristic of nutrient deficiencies. Stunting and poor stand development tend to occur in patches throughout the field as a result of the irregular distribution of nematodes within the soil.

Nematodes associated with mango include Rotylenchulus reniformis, Criconemella sphaerocephala, Helicotylenchus dihystera, and Hemicriconemoides mangiferae. H. mangiferae is known to be pathogenic to mango trees, as well as sapodilla and tamarind, and infestations of this nematode induce a slow decline of mango $(22,23)$.

\section{Chemical Control}

The only products registered for use on mango in Florida that claim nematode suppression are harpin protein, a mixture of plant extracts marketed as Sincocin', and fermentation products of Myrothecium verrucaria strain AARC-0255. Harpin protein activates the systemic acquired resistance of a plant, using the endogenous "immune system" of the plant to ward off nematode attack. Myrothecium verrucaria is a soil fungus that affects juvenile and adult nematodes as well as egg development. The mixture of plant extracts stimulates predatory nematode feeding and inhibits parasitic nematodes.

\section{Key Contacts}

Jonathan Crane is a professor of horticultural science located at the Tropical Research and Education Center in South Florida. He is responsible for research and extension duties associated with tropical fruit. Dr. Crane can be reached at: TREC, 18905 SW 280th St., PO Box 111569, Homestead, FL 33031-3314, (305) 246-7001, jhcr@ufl.edu.

Mark Mossler is a Doctor of Plant Medicine in the Agronomy Department's Pesticide Information Office at the University of Florida's Institute of Food and Agricultural Sciences. He is responsible for providing pest management and pesticide information to the public and governmental agencies. Dr. Mossler can be reached at UF/IFAS PIO, Box 110710, Gainesville, FL 32611, (352) 392 4721, plantdoc@ ufl.edu

\section{References}

1. Personal communication, Dr. J. Crane, August 2008.

2. Evans, E. 2008. Recent Trends in World and U.S. Mango Production, Trade, and Consumption. Food and Resource Economics Department document FE718. Florida Cooperative Extension Service, Institute of Food and Agricultural Sciences, University of Florida.

3. Crane, J.H., Balerdi, C.F., and Maguire, I. 2006. Mango Growing in the Florida Home Landscape. Horticultural Sciences document HS2. Florida Cooperative Extension Service, Institute of Food and Agricultural Sciences, University of Florida.

4. Simmone, A., Bobroff, L.B., Cooper, A., Poirier, S., Murphy, M., Oswald, M.J., and Procise, C. 2007. South Florida Tropicals: Mango. Department of Family, Youth and Community Services fact sheet FCS8532. Florida Cooperative Extension Service, Institute of Food and Agricultural Sciences, University of Florida.

5. Browning, H.W., Childers, C.C., Stansly, P.A., Pena, J., and Rogers, M.E. 2007. 2008 Florida Citrus Pest Management Guide: Soft-bodied Insects Attacking Foliage and Fruit. Entomology and Nematology department document ENY-604. Florida Cooperative Extension Service, Institute of Food and Agricultural Sciences, University of Florida.

6. Denmark, H.A. and Wolfenbarger, D.O. 2008. Redbanded Thrips. Department of Entomology and Nematology, University of Florida, and Florida Department of Agriculture and Consumer Services, Division of Plant Industry Featured Creatures website. 
7. UF/IFAS Pesticide Information Office. 2001. Tropical Fruit Management Survey. Agronomy Department, Institute of Food and Agricultural Sciences, University of Florida.

8. Crane, J.H., and Mossler, M.A. 2006. Pesticides Registered for Tropical Fruit Crops in Florida. Horticultural Sciences document HS929. Florida Cooperative Extension Service, Institute of Food and Agricultural Sciences, University of Florida.

9. Anonymous pricing.

10. JMS Flower Farms labels, Vero Beach, FL..

11. Helena labels, Collierville, TN.

12. Gowan labels, Yuma, AZ.

13. Webb Wright labels, Ft. Myers, FL.

14. Valent BioSciences labels, Libertyville, IL.

15. Bayer CropScience labels, Research Triangle Park, NC.

16. Knapp, J.L. 1999. Citrus Commodity: A Biologic and Economic Assessment of Pesticide Usage. USDA National Agricultural Pesticide Impact Assessment Program Report No. 1-CA-99.

17. Monsanto labels, St. Louis, MO.

18. Pernezny, K. and Marlatt, R.B. 1993. Some Common Diseases of Mango in Florida. Plant Pathology Department document PP23. Florida Cooperative Extension Service, Institute of Food and Agricultural Sciences, University of Florida.

19. DuPont Crop Protection labels, Wilmington, DE.

20. Arysta LifeScience, Cary, NC.

21. Taminco labels, Smyrna, GA.

22. McSorley, R., Campbell, C.W., and Goldweber, S. 1980. Observations on a Mango Decline in South Florida. Proc. Fla. State Hort. Soc. 93:132-133.

23. McSorley, R., and Parrado, J.L. 1982. Spatial Arrangement of Nematodes Around Four Species of Tropical Fruit Trees. Nematropica. Vol. 12, No. 2.

24. AgSci website - accessed 9/08. 